they do nothing in their collective capacity to solve satisfactorily one doubtful point as to the action of a medicine or the treatment of a disease? At this moment we are called upon to cope with a formidable epidemic, the numerous individual observations that have been made concerning which still leave us in doubt whether it be or be not infectious, what is its pathology, and whether it is better treated by laxatives or by astringents. What a noble spectacle would it present, if the two thousand members of our Association would only now agree during the ensuing year to direct their energies to an investigation into the nature and treatment of Asiatic cholera! Might not a central committee be appointed, which, operating through the many branches scattered over the country, would secure chemical, histological, and pathological research, combined with accurate, uniform, and extended observation? Would any of us grudge a small contribution that might serve to remunerate the labours, talent, and consumption of time involved in such an inquiry?

Whatever you resolve on, Gentlemen, to me it is certain, that we have arrived at that epoch in the history of medicine which demands that truth in science and truth in art should no longer be kept asunder; that the traditions of old and less enlightened times should give way to the advancing spirit of inquiry that characterizes the age we live in; and that the separate, and, because separate, too frequently opposing efforts of individuals should merge into the catholic endeavour of solving by union and mutual help those questions which it has been demonstrated have baffled solitary research. The whole scope and tendency of the modern science and art of medicine indicate that future progress can alone be secured by combined labour: and I can conceive no more worthy, as there is no more appropriate, object for the.consideration of this Association, than the manner and methods by which this great work could, through its agency, be prosecuted and accomplished.

\title{
COMMISSIONS IN THE INDIAN MEDICAL SERVICE.
}

THE following Candidates were successful at the Competitive Examination at Chelsea in March last, and have undergone a course of instruction at the Army Medical School: with the total number of marks (maximum 6900) obtained at the Examinations at Chelsea and at Netley :-

\begin{tabular}{|c|c|c|c|c|c|}
\hline & Studied at & Marks. & Names. & & \\
\hline & London, & 5060 & Holmested, T. & Lon & \\
\hline & ourgh, & 5060 & herson, J. & een, & \\
\hline O. C. & nd, & 5036 & $\mathrm{n}, \mathrm{R}$ & & \\
\hline J. T. & leen, & 4600 & A. & irgh, & \\
\hline , R. M. & in, & 4580 & er, A. H. & & \\
\hline urton, W. P. & urgh, & 4460 & 'T'. & & \\
\hline E. A. & Irel & 4370 & ey, S. C & & \\
\hline r, D. P. & Irel & 4320 & & & \\
\hline D. F. & \& Lon. & 4135 & on, P. J. & & \\
\hline vay, W. W. & leen, & 4098 & M'Vittie, C. E. & \& Irel. & \\
\hline Eades, L. E. & Edin. \& Dub. & 4090 & Cullinan, C. M. & Ireland, & \\
\hline & Dublin, & 40 & Mayer, H. C. & . \& Irel. & \\
\hline $\mathrm{Hu}$ & Edinburgh, & 3945 & Rickard, F. M & Lor & \\
\hline M'Kenz' & Edinburgh, & 3936 & Bakman, D & Edinburgh, & \\
\hline
\end{tabular}

\section{PUBLICATIONS RECEIVED.}

Da Costa,-Medical Diagnosis, with special Reference to Practical Medicine. By J. M. Da Costa, M.D. Second Edition. Philadelphia, 1866.

Howe,-Reflections on Cholera. By A. H. Howe, M.D., etc. London, 1866 .

Human Blightand Cattle Blight- the Cholera and Cattle Plague. London, 1866.

Sédillot,-Traité de Médecine Opératoire,
Bandages et Apparéils. Par le Dr Charles Sédillot. Tome Seconde. Troisième Édition. Paris, 1866.

Sedgwick,-The Nature of Cholera as a Guide to Treatment. By William Sedgwick, M.R.C.S., etc. London, 1866.

Voisin,-Contribution à l'Histoire des Mariages entre Consanguins. Par le Dr A. Voisin. Paris, 1866. 